JKKP: Jurnal Kesejahteraan Keluarga dan Pendidikan

http://doi.org/10.21009/JKKP

DOI: doi.org/10.21009/JKKP.032.08

E-ISSN: 2597-4521

\title{
HUBUNGAN POLA ASUH ORANG TUA DENGAN KEPEDULIAN SOSIAL REMAJ A
}

\author{
Hana Rizkia Aditia 1,a), Hamiyati 1,b), Rusilanti 2,c) \\ a)hanaaditia@gmail.com, b)hamiyati32@yahoo.com , c)rusilanti@gmail.com \\ 1)P rogram Studi Pendidikan Kesejahteraan Keluarga \\ 2) Program Studi Pendidikan Tata Boga \\ Fakultas Teknik, Universitas Negeri J akarta \\ J In. Rawamangun Muka, J akarta Timur. 13220
}

\begin{abstract}
Abstrak
Kepedulian sosial adalah perasaan bertanggung jawab atas kesulitan yang dihadapi oleh orang lain dan terdorong untuk melakukan sesuatu untuk mengatasinya. Kepedulian tidak bisa tumbuh pada diri setiap orang, melainkan membutuhkan proses latihan dan didikan. Pola pengasuhan yang dilakukan oleh keluarga berperan sangat penting. Penelitian ini bertujuan untuk mengetahui dan menganalisis hubungan antara pola asuh orang tua dengan kepedulian sosial remaja kelas VIII SMP Negeri 238 Duren Tiga, Pancoran, Jakarta Selatan, selama bulan Januari 2016 hingga Juli 2016. Populasi penelitian adalah seluruh siswa kelas VIII SMP Negeri 238 Jakarta sejumlah 209 siswa, sedangkan sampel penelitian diambil dengan metode simple random sampling dengan jumlah 137 siswa. Pengambilan data dilakukan dengan observasi, dokumentasi dan angket. Analisis data secara deskriptif, uji prasyarat, dan pengujian hipotesis dengan bantuan program Microsoft Office Excel 2013. Hasil uji normalitas chi kuadrat berdistribusi normal. Koefisien korelasi Product Moment dari Pearson menghasilkan $r_{x y}=0,471$. Hasil hipotesis penelitian dan uji mengenai hubungan diperoleh bahwa terdapat hubungan yang positif antara pola asuh orang tua dengan kepedulian sosial remaja kelas VIII SMP Negeri 238 Jakarta. Koefisien determinasi yang diperoleh sebesar $22 \%$ menunjukkan besarnya kepedulian sosial remaja yang dipengaruhi oleh pola asuh orang tua.
\end{abstract}

Kata Kunci: Pola Asuh Orang Tua, Kepedulian Sosial, Remaja

The Relationship of Parenting Pattem with Adolescent Social Care

\begin{abstract}
Social care is feeling responsible for the difficulties faced by others where a person dwells and compelled to do something about it. Concern can not grow in everyone, but requires a process of training and education. Patern of parenting by the family plays an important role. This study aims to identify and analyze the relationship between parenting pattern with adolescent social care class VIII SMPN 238 Duren Tiga, Pancoran, South J akarta, during the month of J anuary 2016 to J uly 2016. The study population was all students of class VIII SMP Negeri 238 J akarta amount 209 students, while samples were taken by simple random sampling method with the number of 137 students. Data were collected by observation, documentation and questionnaires. Analysis of descriptive data, the prerequisite test, and hypothesis testing with the help of Microsoft Office Excel 2013. The results of the chi-square test for normality normal distribution. The correlation coefficient of Pearson Product Moment generating rxy $=0.471$. The results of research and test hypotheses about the relationship shows that there is a positive relationship between
\end{abstract}


parenting parents with adolescent social care class VIII SMP Negeri 238 J akarta. The coefficient of determination obtained by $22 \%$ shows the magnitude of social concern adolescents is influenced by parenting parents.

Keywords: Parenting Parents, Social Care, Adolescent

\section{PENDAHULUAN}

Dalam kehidupan sehari-hari, setiap orang selalu melakukan hubungan sosial dengan orang lain atau kelompok-kelompok tertentu. Sebagai makhluk sosial yang membutuhkan pertolongan orang lain, maka sebaiknya sebagai manusia harus sukarela menolong atau memberikan bantuan terhadap orang lain. Perilaku menolong ini biasa disebut perilaku prososial atau kepedulian sosial. Kepedulian sosial adalah perasaan bertanggung jawab atas kesulitan yang dihadapi oleh orang lain dimana seseorang berdiam dan terdorong untuk melakukan sesuatu untuk mengatasinya. Kepedulian untuk melakukan semua itu tidak bisa tumbuh pada diri setiap orang, melainkan membutuhkan proses melatih dan mendidik (Buchari Alma, dkk, 2010). Disini pola pengasuhan berperan sangat penting, terutama yang dilakukan oleh keluarga.

Pola asuh merupakan pencerminan tingkah laku orang tua yang diterapkan kepada anak secara dominan. Dikatakan dominan karena pola asuh yang diterapkan dilakukan secara penuh dan terus menerus, sepanjang kehidupan anak. Tidak ada satu hari pun lepas dari asuhan dan didikan orangtua, bahkan ketika anak sudah dewasa. Dalam mendidik anak terdapat berbagai macam pola asuh yang bisa dipilih dan digunakan oleh orangtua. Diantaranya pola asuh otoriter, demokratis dan otoritatif (Musaheri, 2007).

Pola asuh yang berbeda-beda berkaitan erat dengan sifat kepribadian yang berbeda-beda pada anak. Contohnya pola asuh otoriter cenderung bersifat keras, selalu mengekang dan bersifat kaku kepada anak. Dalam pengasuhan seperti itu anak akan mudah stress, pemurung, penakut, dan tidak mudah bersahabat dengan orang lain. Jika orang tua mendidik anak dengan baik, maka anak itu pun akan menjadi baik. Dan begitu pun sebaliknya. Hal tersebut akan memberikan dampak yang negatif terhadap perkembangan psikis dan sosial anak.

Penelitian yang dilakukan Ike Marlina (2014) pada anak SD di Kecamatan Umbulharjo Yogyakarta, ditemukan fakta bahwa pola asuh orang tua sangat mempengaruhi terhadap kecerdasan emosi anak. Dari 90 siswa, orang tua lebih banyak menerapkan pola asuh otoritatif $19,67 \%$ siswa tergolong kecerdasan emosi tinggi, $67,78 \%$ kecerdasan emosi sedang, dan $15,55 \%$ kecerdasan emosi rendah. Terbukti terdapat pengaruh yang positif dan signifikan antara pola asuh terhadap kecerdasan emosi.

Kecerdasan emosi menjadikan seseorang lebih mendalami dalam berbuat dan berperilaku, karena Emotional Quotient (EQ) merupakan salah satu aspek kecerdasan dalam menentukan efektifitas penggunaan kecerdasan yang konvensional. Monks (Ermi Yantiek, 2014) menjelaskan kecerdasan emosi merupakan kemampuan untuk mengelola perasaan, kemampuan untuk mempersepsi situasi, bertindak sesuai dengan persepsi tersebut dan menentukan potensi seseorang untuk mempelajari keterampilan praktis yang didasarkan pada kesadaran diri, motivasi, pengaturan diri, empati dan kecakapan dalam membina hubungan dengan orang lain.

Penelitian yang dilakukan Anna Kurniawati (2013) juga membuktikan adanya hubungan antara pola asuh demokratis dan kecerdasan emosi dengan perilaku prososial pada remaja SMP Cita Hati. Hasil penelitian disimpulkan bahwa pola asuh demokratis dan kecerdasan emosional berkorelasi sangat signifikan dengan perilaku prososial. Sumbangan efektif kedua variabel $X$ terhadap $Y$ ditunjukkan dari harga $r^{2}=0,707$ yang berarti variabel pola asuh demokratis dan kecerdasan emosi secara bersama-sama memberikan pengaruh sebesar $70,7 \%$ terhadap perilaku prososial pada remaja. 
Anak usia sekolah menengah atau remaja seringkali dikenal dengan masa krisis, fase mencari jati diri. Remaja sudah tidak masuk ke dalam golongan anak-anak, tetapi belum juga dapat diterima secara penuh untuk masuk kegolongan orang dewasa. Anak remaja sangat mudah terpengaruh oleh lingkungan dan sebagainya, akibatnya akan muncul kekecewaan dan penderitaan, meningkatnya konflik dan pertentangan, impian dan khayalan, pacaran dan percintaan, keterasingan dari kehidupan dewasa dan norma kebudayaan. Pada masa ini juga anak sudah dapat membedakan mana yang baik dan buruk, serta berfikir dengan logika (M. Ali Asrori, 2011).

Menurut Komisi Perlindungan Anak Indonesia (KPAI, 2012) Negara dan semua pihak terkait harus bekerja lebih keras untuk menyelamatkan anak-anak telantar atau menghadapi berbagai persoalan lain. Sebab, ternyata jumlah anak yang tertimpa masalah pola asuh jumlahnya sangat besar, mencapai 4,1 juta orang. Diantaranya adalah 5.900 anak menjadi korban kekerasan, 34.000 di antaranya anak jalanan, 3.600 anak berhadapan dengan hukum (ABH). Kasus-kasus yang menjadi masalah baru berkaitan dengan pola asuh anak, mengalami peningkatan dari tahun ke tahun. Tanggung jawab serta perilaku tumbuh kembang anak-anak yang paling utama adalah berada di tangan kedua orang tua dan keluarga besarnya.

Kepala Humas Polri Daerah Metro Jaya Resor Metropolitan Jakarta Selatan Sektor Tebet Bapak Dede Kurniawan mengatakan bahwa terdapat kasus kejahatan yang terjadi di Daerah Tebet Jakarta Selatan diantaranya ada kekerasan/tawuran sebanyak 18 kasus, penganiayaan 35 kasus, pencurian 29 kasus, perbuatan tidak menyenangkan 3 kasus, penganiayaan ringan 8 kasus, dan narkoba 33 kasus. Sebagian besar anak dan remaja yang terlibat kasus kejahatan berasal dari keluarga yang kurang peduli bahkan tidak peduli dengan anaknya, sehingga mereka mencari pelampiasan kepada temannya di lingkungan sekolah, dan keluarga.

Dari beberapa penelitian tersebut dapat diketahui bahwa terdapat hubungan dan pengaruh antara pola asuh orang tua, kecerdasan emosi dan prososial atau kepedulian sosial. Pola asuh sangat berpengaruh kepada kepedulian sosial, kepedulian sosial anak dapat dilihat dari penerapan pola asuh yang dilakukan oleh orang tua. Kecerdasan emosi juga sangat berpengaruh kepada kepedulian sosial karena anak yang memiliki kecerdasan emosi yang tinggi memiliki tingkat kepedulian sosial yang tinggi, sementara anak yang memiliki kecerdasan emosi rendah memiliki tingkat kepedulian sosial yang rendah.

\section{METODOLOGI PENELTIAN}

Penelitian ini dilakukan di kelas VIII SMP Negeri 238 Duren Tiga, Pancoran, Jakarta Selatan, selama bulan Januari 2016 hingga Juli 2016. Populasi penelitian adalah seluruh siswa kelas VIII SMP Negeri 238 Jakarta sejumlah 209 siswa, sedangkan sampel penelitian diambil dengan metode simple random sampling dengan jumlah 137 siswa. Pengambilan data dilakukan dengan observasi, dokumentasi dan angket. Analisis data secara deskriptif, uji prasyarat, dan pengujian hipotesis dengan bantuan program Micros oft Office Excel 2013. Hasil uji normalitas chi kuadrat berdistribusi normal. Koefisien korelasi Product Moment dari Pearson menghasilkan $\mathbf{r}_{x y}=$ 0,471 .

\section{HASIL DAN PEMBAHASAN}

Berdasarkan penelitian yang telah dilakukan, pada remaja siswa kelas VIII SMP Negeri 238 Jakarta diketahui rhitung sebesar 0,471 dan rtabel sebesar 0,168 . Sehingga dapat disimpulkan rhitung 0,471 lebih dari rtabel 0,168 , maka dapat disimpulkan bahwa terdapat hubungan yang positif antara pola asuh orang tua dengan kepedulian sosial remaja SMP Negeri 238 Jakarta. Hasil korelasi tersebut masuk kedalam kategori cukup kuat atau sedang. Dan diketahui thitung sebesar 6,207 > ttabel sebesar 1,978, sehingga dapat disimpulkan bahwa terdapat hubungan positif yang signifikan antara pola asuh orang tua dengan kepedulian sosial remaja. 
Dalam penelitian ini terdapat hubungan yang positif dan signifikan antara pola asuh orang tua dengan kepedulian sosial remaja dengan sampel 137 responden. Dilihat dari derajat hubungan pola asuh orang tua dengan kepedulian sosial remaja siswa kelas VIII SMP Negeri 238 Jakarta hanya mencapai $22 \%$ dan sisanya $78 \%$ ditentukan oleh faktor lain seperti teman sebaya, role model, kecerdasan emosi, dan lain sebagainya. Cara orang tua memberikan pengertian mengenai kepedulian sosial kepada anak sangatlah penting agar anak memiliki nilai sosial yang tinggi.

Adanya hubungan yang positif antara pola asuh orang tua dengan kepedulian sosial remaja dipertegas oleh Musaheri (2007) mengemukakan bahwa pola asuh merupakan suatu kegiatan yang dilakukan secara terpadu dalam jangka waktu yang lama oleh orang tua kepada anaknya dengan tujuan untuk membimbing, membina dan melindungi anak. Pola asuh merupakan interaksi antara orang tua dengan anak, interaksi disini termasuk ekspresi sikap, nilai, perhatian dalam membimbing, mengurus, dan melatih perilaku anak. Maka dari itu orang tua perlu memberikan pola asuh yang baik bagi anak dan mengajarkan nilai- nilai sosial, karena bagaimana cara orang tua mendidik anak sangat penting agar anak mempunyai nilai sosial yang tinggi.

Selain itu juga sejalan dengan pendapat Buchari Alma (2010) keluarga merupakan lingkungan sosial terkecil yang dialami oleh seorang manusia. Lingkungan inilah yang pertama kali mengajarkan manusia bagaimana berinteraksi. Hal yang penting diketahui bahwa lingkungan keluarga membawa perasaan sosial yang pertama. Misalnya dengan perasaan simpati anak kepada orang tua, perasaan itu akan muncul ketika telah diurus dan dirawat dengan sebaikbaiknya. Dari perasaan itu tumbuhlah rasa cinta dan kasih sayang anak kepada orang tua dan anggota keluarga yang lain, sehingga akan timbul sikap saling peduli.

Peduli sosial merupakan sikap dan tindakan yang selalu ingin memberi bantuan kepada masyarakat yang membutuhkannya. Kepedulian sosial suatu nilai penting yang harus dimiliki setiap orang karena terkait dengan nilai kejujuran, kasih sayang, rendah hati, keramahan, kebaikan, dan sikap selalu ingin membantu orang lain. Kepedulian sosial tidak pernah lepas dari kesadaran sosial. Kesadaran sosial merupakan kemampuan untuk memahami arti dari situasi tersebut. Hal tersebut sangat tergantung dari bagaimana empati terhadap orang lain.

Buchari Alma, dkk (2010) membagi bentuk-bentuk kepedulian, yaitu:

1. Di Lingkungan Keluarga

Keluarga merupakan lingkungan sosial terkecil yang dialami oleh seorang manusia. Lingkungan inilah yang pertama kali mengajarkan manusia bagaimana berinteraksi. Seyogyanya manusia hidup berkeluarga adalah untuk mencari kebahagiaan. Tetapi apa yang diharapkannya tidak selalu sesuai dengan harapan. Hal yang paling penting diketahui bahwa lingkungan rumah itu akan membwa perkembangan perasaan sosial yang pertama.

2. Di Lingkungan Masyarakat

Lingkungan masyarakat pedesaan yang masih memiliki tradisi yang kuat masih tertanam sikap kepedulian sosial yang sangat erat. Ketika ada suatu kegiatan yang dilakukan oleh satu keluarga, maka keluarga lain dengan tanpa imbalan akan segera membantu dengan berbagai cara. Misalnya saat mau mendirikan rumah, anggota keluarga yang lain menyempatkan diri untuk berusaha membantunya.

3. Di Lingkungan Sekolah

Sekolah tidak hanya sebagai tempat untuk belajar meningkatkan kemampuan intelektual, akan tetapi juga membantu anak untuk dapat mengembangkan emosi, berbudaya, bermoral, bermasyarakat, dan kemampuan fisiknya. Abu Ahmadi \& Uhbiyati (2001) menjelaskan bahwa, fungsi sekolah sebagai lembaga sosial adalah membentuk manusia social yang dapat bergaul dengan sesama manusia secara serasi walaupun terdapat unsur perbedaan tingkat sosial ekonomi, perbedaan agama, ras, peradaban, bahasa dan lain sebagainya. 


\section{KESIMPULAN}

Berdasarkan pengolahan deskriptif, pengolahan data statistik dan analisis data yang telah diuraikan sebelumnya maka dapat ditarik kesimpulan sebagai berikut:

1. Berdasarkan skor masing- masing responden, pola asuh orang tua remaja kelas VIII SMP Negeri 238 Jakarta memiliki dimensi dominan atau dimensi yang memiliki presentase terbesar yaitu dimensi pola asuh otoriter sebesar $77 \%$, dimensi pola asuh demokratis $75 \%$ dan yang terkecil adalah dimensi pola asuh permisif $52 \%$.

2. 2. Berdasarkan skor masing- masing responden, kepedulian sosial remaja kelas VIII SMP Negeri 238 Jakarta memiliki dimensi dominan atau dimensi yang memiliki presentase terbesar yaitu dimensi pemahaman dan empati sebesar $85 \%$, dimensi kesadaran untuk bersikap sebesar $77 \%$ dan dimensi kemampuan untuk bertindak sebesar $60 \%$.

3. Perhitungan korelasi menujukkan $r_{\text {hitung }}$ sebesar 0,471 dan rtabel sebesar 0,168 . Berdasarkan hasil tersebut maka $r_{\text {hitung }}$ lebih besar dari $r_{\text {tabel }}(0,471>0,168)$. Maka terdapat hubungan yang positif antara pola asuh orang tua dengan kepedulian sosial remaja. Hasil tersebut diinterprestasikan dengan tabel kriteria koefisien korelasi dan masuk dalam kategori cukup kuat atau sedang.

4. Perhitungan uji "t" korelasi menunjukkan $t_{\text {hitung }}$ sebesar 6,207 dan $t_{\text {tabel }} 1,978$. Dengan demikian thitung lebih dari $t_{\text {tabel }}(6,207>1,978)$. Hal ini menunjukkan bahwa kedua variabel mempunyai hubungan positif yang signifikan.

5. Perhitungan koefisien determinasi sebesar $22 \%$ menunjukkan bahwa kepedulian sosial remaja kelas VIII SMP Negeri 238 Jakarta ditentukan oleh pola asuh orang tua, sedangkan $78 \%$ ditentukan oleh faktor lain, seperti teman sebaya, role model, kecerdasan emosional dan lain sebagainya.

6. Uji hipotesis penelitian mengenai hubungan pola asuh orang tua dengan kepedulian sosial remaja kelas VIII SMP Negeri 238 Jakarta menunjukkan bahwa terdapat hubungan yang positif diantara keduanya.

\section{DAFTAR PUSTAKA}

Abu, A., Nur, U. 2001. Ilmu Pendidikan. RinekaCipta. Jakarta.

Anna, K.H. 2013. Hubungan Pola Asuh Demokratis dan Kecerdasan Emosi dengan Perilaku Prososial Pada Remaja. Skripsi. Magister Psikologi Universitas 17 Agustus 1945. Surabaya. Indonesia

Buchari, A. dkk. 2010. Pembelajaran Studi Sosial. Alfabeta. Bandung.

Depdiknas. 2008. Kamus Besar Bahasa Indonesia. Gramedia Pustaka Utama. Jakarta.

Depdiknas. 2012. Kamus Besar Bahasa Indonesia. Gramedia Pustaka Utama. Jakarta.Ermi, Y. 2014. Kecerdasan Emosi, Kecerdasan Spiritual dan Perilaku Prososial Remaja.Skripsi. Magister Psikologi Universitas17 Agustus1945. Surabaya. Indonesia

Ike, M. 2014. Pengaruh Pola Asuh Orang Tua Terhadap Kecerdasan Emosi. Skripsi. PGSD UNY. Yogyakarta. Indonesia

Komisi Perlindungan Anak Indonesia (KPAl). 2015. Jutaan Anak Alami Masalah Sosial. http://www.kpai. go.id/ berita/ kpai-jutaan-anak-alami-masalah-sosial. Tanggal akses $15 \mathrm{Feb}$ 2016.

Mohammad Ali \& Asrori. 2011. Psikologi Remaja, Perkembangan Peserta Didik. Bumi Aksara. Jakarta.

Musaheri. 2007. Pengantar Pendidikan. IRCiSoD. Yogyakarta 